\title{
Methionine plus Cystine Levels for Light Laying Hens on Production Phase
}

\author{
Níveis de Metionina + Cistina para Galinhas Poedeiras Leves na Fase Postura \\ Niveles de Metionina + Cistina para Gallinas Ponedoras en Fase de Puesta
}

Received: 02/09/2021 | Reviewed: 02/20/2021 | Accept: 02/22/2021 | Published: 02/28/2021

Marcelo Helder Medeiros Santana
ORCID: https://orcid.org/0000-0002-4578-5716
Instituto Federal de Educação, Ciência e Tecnologia da Parába, Brazil
E-mail: marcelo.santana@ifpb.edu.br
Fernando Guilherme Perazzo Costa
ORCID: https://orcid.org/0000-0002-2044-1247
Universidade Federal da Paraíba, Brazil
E-mail: perazzo63@gmail.com
Ricardo Romão Guerra
ORCID: https://orcid.org/0000-0001-8226-8606
Universidade Federal da Paraíba, Brazil
E-mail: rromaoguerra@gmail.com
Patrícia Emília Naves Givisiez
ORCID: https://orcid.org/0000-0002-2480-1780
Universidade Federal da Paraíba, Brazil
E-mail: patriciagivisiez@ gmail.com
Jalceyr Pessoa Figueiredo Júnior
ORCID: https://orcid.org/0000-0002-2044-1247
Secretaria de Estado de Agropecuária, Brazil
E-mail: peudure@ hotmail.com
Matheus Ramalho de Lima
ORCID: https://orcid.org/0000-0002-9897-6209
Universidade Federal do Sul da Bahia, Brazil
E-mail: mrlmatheus@gmail.com

\begin{abstract}
The objective of this study was to evaluate the levels of sulfur amino acids in the diets of laying hens of 34-50 weeks of age. 336 Dekalb White birds were distributed in a completely randomized design with six treatments, 14 replicates of four birds each. The diets consisted in a control treatment, formulated to meet the nutritional requirements of sulfur amino acids according to the NRC (1994) and five diets varying in methionine plus cystine level $(0.536,0.603,0.670$, $0.737,0.804 \%$ ). Performance, egg quality and histological data were evaluated. There was a significant quadratic effect for production and egg mass and mass and dozen conversion per eggs, with methionine plus cystine estimations of $0.691 \%, 0.689 \%, 0.737 \%$ and $0.730 \%$, respectively. Methionine plus cystine levels significantly affected the histology of tissues. The level of $0.737 \%$ of digestible methionine plus cystine, with $90 \%$ of methionine plus cystine: lysine ratio, and $756.53 \mathrm{mg} / \mathrm{bird} / \mathrm{day}$ of consumption, is recommended to light laying hens in the production phase.
\end{abstract}

Keywords: Egg quality; Nutritional requirements; Histological analysis.

\section{Resumo}

O objetivo deste estudo foi avaliar os níveis de aminoácidos sulfurados em dietas para poedeiras comerciais de 34 a 50 semanas de idade. 336 aves Dekalb White foram distribuídas em um delineamento inteiramente casualizado, com seis tratamentos, 14 repetições de quatro aves cada. As dietas consistiram em um tratamento controle, formulado para atender às exigências nutricionais de aminoácidos sulfurados de acordo com o NRC (1994) e cinco dietas variando no teor de metionina + cistina $(0,536,0,603,0,670,0,737,0,804 \%)$. Foram avaliados os dados de desempenho, qualidade dos ovos, além de dados histológicos. Houve efeito quadrático significativo para produção e massa e massa de ovos e conversão de dúzias por ovo, com estimativas de metionina + cistina de 0,691\%,0,689\%, 0,737\% e 0,730\%, respectivamente. Os níveis de metionina + cistina afetaram significativamente a histologia dos tecidos. Recomenda-se o nível de $0,737 \%$ de metionina digestível + cistina, com uma relação de $90 \%$ de metionina + cistina:lisina e 756,53 $\mathrm{mg} / \mathrm{ave} /$ dia de consumo para poedeiras leves em fase de produção.

Palavras-chave: Análises histológicas; Qualidade dos ovos; Requerimentos nutricionais.

\section{Resumén}

El objetivo de este estudio fue evaluar los niveles de aminoácidos azufrados en dietas para gallinas ponedoras de 34 a 50 semanas de edad. Se distribuyeron 336 aves Dekalb White en un diseño completamente al azar, con seis tratamientos, 14 repeticiones de cuatro aves cada una. Las dietas consistieron en un tratamiento control, formulado para cubrir los 
requerimientos nutricionales de aminoácidos azufrados según la NRC (1994) y cinco dietas variando en el contenido de metionina + cistina $(0.536,0.603,0.670,0.737,0.804 \%)$. Se evaluaron los datos de rendimiento, la calidad del huevo y los datos histológicos. Hubo un efecto cuadrático significativo para la producción de huevos y la masa y la masa y conversión de docenas por huevo, con estimaciones de metionina + cistina de $0.691 \%, 0.689 \%, 0.737 \%$ y $0.730 \%$, respectivamente. Los niveles de metionina + cistina afectaron significativamente la histología del tejido. Se recomienda el nivel de $0,737 \%$ de metionina digestible + cistina, con una relación del 90\% de metionina + cistina: lisina y 756,53 mg/ave/ día de consumo para gallinas ponedoras ligeras en fase de producción.

Palabras clave: Calidad del huevo; Requerimientos nutricionales; Análisis histológicos.

\section{Introduction}

Recent research has shown that in the year 2019, Brazilian production hit a record, producing about 49 billion eggs, representing an increase of 5 billion units when compared to the previous year. One of the explanations for this raise in production is the increase in egg consumption by the Brazilian, which in 2016 consumed only 190 eggs/year, increasing to 230 eggs/year in 2019 (ABPA, 2020).

Amino acids are directly linked to the egg production and therefore have an important role on feed conversion and efficiency of laying hens, as well as increased utilization of nitrogen, thus avoiding higher levels of excretion to the environment. Moreover, they are essential components of the eggs and the proteins that are present in the albumen and yolk (Leeson et al., 2001).

Methionine is the first limiting amino acid in the diets of laying hens based on corn and soybean meal. It is essential for the maintenance of egg production in a laying cycle and is also directly linked to the quality of the product.

Moreover, amino acid imbalance in the diet may cause numerous metabolic damages, such as increased nitrogen excretion, liver and kidney lesions, and a lower development of intestinal villi and cells of the reproductive tract of laying hens.

Thus, the aim of this work was to evaluate the levels of methionine plus cystine in the diets of laying hens in the production phase.

\section{Materials and Methods}

Three hundred and thirty six Dekalb White birds aged 34 weeks were used. The birds were housed in laying cages with food and water ad libitum and light for 17 hours (natural + artificial). The animals were distributed in a completely randomized design with six treatments and fourteen repetitions with four animals per experimental unit. The project had ethical approval from the Animal Use and Care Committee of the Federal University of Paraiba, Brazil, under protocol number 149/2015.

The experimental diets (Table 1) were prepared as follows: a control treatment, formulated to meet the nutritional requirements following the recommendations of (NRC, 1994); and the other treatments were established according to the recommendations of the Brazilian Poultry and Swine Tables (Rostagno et al., 2011), except for methionine plus cystine, which were included in percentages of $80,90,100,110$ and $120 \%$ and resulted in levels of $0.536 ; 0.603 ; 0.670 ; 0.737$ and $0.804 \%$ methionine plus cystine. The diets were supplemented with DL-Methionine-99\% (0.093, 0.160, 0.227, 0.294, 0.361\%), replacing the starch to achieve the dietary levels. 
Table 1 - Ingredients and chemical composition of experimental diets.

\begin{tabular}{|c|c|c|c|c|c|c|c|}
\hline \multirow{2}{*}{ Ingredients } & & \multirow{2}{*}{$\begin{array}{c}\text { NRC } \\
(1994)^{*}\end{array}$} & \multicolumn{5}{|c|}{ Rostagno et al. (2011) } \\
\hline & & & $80 \%$ & $90 \%$ & $100 \%$ & $110 \%$ & $120 \%$ \\
\hline Corn & & 66.797 & 71.675 & 71.675 & 71.675 & 71.675 & 71.675 \\
\hline Soybean meal & & 16.077 & 13.360 & 13.360 & 13.360 & 13.360 & 13.360 \\
\hline Limestone & & 9.654 & 9.587 & 9.587 & 9.587 & 9.587 & 9.587 \\
\hline Calcium phosphate & & 1.195 & 1.158 & 1.158 & 1.158 & 1.158 & 1.158 \\
\hline Sodium chloride & & 0.435 & 0.523 & 0.523 & 0.523 & 0.523 & 0.523 \\
\hline Choline chloride & & 0.070 & 0.070 & 0.070 & 0.070 & 0.070 & 0.070 \\
\hline Vitamin premix ${ }^{2}$ & & 0.100 & 0.100 & 0.100 & 0.100 & 0.100 & 0.100 \\
\hline Mineral premix ${ }^{1}$ & & 0.050 & 0.050 & 0.050 & 0.050 & 0.050 & 0.050 \\
\hline Corn gluten meal $60 \%$ & & 4.281 & 2.642 & 2.642 & 2.642 & 2.642 & 2.642 \\
\hline L-Lysine-HCl & & 0.211 & 0.222 & 0.222 & 0.222 & 0.222 & 0.222 \\
\hline L-Threonine & & 0.000 & 0.103 & 0.103 & 0.103 & 0.103 & 0.103 \\
\hline L-Triptophan & & 0.000 & 0.040 & 0.040 & 0.040 & 0.040 & 0.040 \\
\hline DL-Methionine & & 0.179 & 0.093 & 0.160 & 0.227 & 0.294 & 0.361 \\
\hline Corn Starch & & 0.936 & 0.361 & 0.294 & 0.227 & 0.160 & 0.093 \\
\hline Total & & 100 & 100 & 100 & 100 & 100 & 100 \\
\hline Chemical Composition & Unit & & & & & & \\
\hline Crude Protein & $\%$ & 18.800 & 16.500 & 16.500 & 16.500 & 16.500 & 16.500 \\
\hline Metabolizable Energy & $\mathrm{kcal} / \mathrm{kg}$ & 2800.0 & 2800.0 & 2800.0 & 2800.0 & 2800.0 & 2800.0 \\
\hline Calcium & $\%$ & 4.060 & 4.020 & 4.020 & 4.020 & 4.020 & 4.020 \\
\hline Available Phosphorus & $\%$ & 0.310 & 0.300 & 0.300 & 0.300 & 0.300 & 0.300 \\
\hline Digestible Arginine & $\%$ & 0.880 & 0.736 & 0.736 & 0.736 & 0.736 & 0.736 \\
\hline Digestible Isoleucine & $\%$ & 0.810 & 0.559 & 0.559 & 0.559 & 0.559 & 0.559 \\
\hline Digestible Lysine & $\%$ & 0.860 & 0.736 & 0.736 & 0.736 & 0.736 & 0.736 \\
\hline Digestible Met + Cys & $\%$ & 0.730 & 0.536 & 0.603 & 0.670 & 0.737 & 0.804 \\
\hline Digestible Threonine & $\%$ & 0.590 & 0.559 & 0.559 & 0.559 & 0.559 & 0.559 \\
\hline Digestible Triptophan & $\%$ & 0.159 & 0.169 & 0.169 & 0.169 & 0.169 & 0.169 \\
\hline Sodium & $\%$ & 0.190 & 0.225 & 0.225 & 0.225 & 0.225 & 0.225 \\
\hline Chlorine & $\%$ & 0.303 & 0.355 & 0.355 & 0.355 & 0.355 & 0.355 \\
\hline Potassium & $\%$ & 0.532 & 0.580 & 0.580 & 0.580 & 0.580 & 0.580 \\
\hline Electrolytic Balance & $\mathrm{mEq} / \mathrm{kg}$ & 0.419 & 0.450 & 0.450 & 0.450 & 0.450 & 0.450 \\
\hline
\end{tabular}

* Feed formulated based on total amino acids. ${ }^{1}$ Inorganic mineral premix per kg of product: Mn, $20 \mathrm{~g} ; \mathrm{Fe}, 10 \mathrm{~g} ; \mathrm{Zn}, 13,7 \mathrm{~g} ; \mathrm{Cu}, 2,5 \mathrm{~g} ; \mathrm{Se}, 0,063 \mathrm{~g} ; \mathrm{I}, 0,19 \mathrm{~g}$; and vehicle q.s.p., $500 \mathrm{~g} .{ }^{2}$ Vitaminic premix per kg of feed: Vit. A - 15.000.000 Ul, Vit. $\mathrm{D}_{3}-1.500 .000 \mathrm{Ul}$, Vit. E - 15.000 Ul, Vit.B 1 - 2,0 g, Vit.B ${ }_{2}-4,0 \mathrm{~g}$, Vit B6 $-3,0$ g, Vit. $B_{12}-0,015$ g, Nicotinic acid -25 g, Pantotenic acid- 10 g, Vit. $K_{3}-3,0$ g, Folic acid- 1,0 g, Bacitracin zinc -10 g, Selenium -250 mg. ${ }^{3}$ Antioxidant BHT $-10 \mathrm{~g}$, and vehicle. Q.s.p. $-1.000 \mathrm{~g}$. Source: Authors.

Feed intake (g/bird), egg production (\%), egg weight (g), egg mass (g), egg mass conversion (g/g), egg dozen conversion $(\mathrm{kg} / \mathrm{dozen})$, yolk percentage $(\%)$, shell percentage $(\%)$, albumen percentage $(\%)$, shell thickness (mm), specific gravity $(\mathrm{g} / \mathrm{mL})$, methionine plus cystine intake (mg/bird), lysine intake (mg/bird), gut weight (g/bird), liver weight (g/bird), abdominal fat weight (g/bird) and spleen weight (g/bird) were determined. 
For histopathological analyses, five birds per treatment were sacrificed at the end of the experimental period. The liver, kidney, small intestine, uterus and magnum were weighed or measured and fragments were immersed in fixative metacarn $(60 \%$ methanol, $30 \%$ chloroform and 10\% acetic acid) for 12 hours and subsequently transferred to $70 \%$ alcohol. Tissue samples were then included in Paraplast, and 5-micrometer serial sections were performed. Hematoxylin and eosin, periodic acid Schiff (PAS) and Masson dyes were used for histological analysis. The photomicrographs were obtained using a microscope coupled to an Olympus BX-51 and the images scanned at KS 400.3 (Zeiss) software.

The feed was weighed at the beginning and end of each cycle of experimental evaluation (28 days) to determine feed intake, feed conversion per weight and per dozen eggs, and methionine plus cystine and lysine intakes. The eggs were collected daily from each experimental unit to determine of egg production. Feed conversion per dozen eggs was calculated by dividing feed intake by the number of dozens of eggs produced; whereas conversion by egg mass was obtained by dividing feed intake by egg mass produced. The latter was calculated by multiplying the production by egg weight.

Eggs, yolk and albumen were weighed on a digital scale $(0.001 \mathrm{~g})$ to calculate the average weight of the eggs, and the percentages of yolk and albumen. Shell percentage was calculated after the shells were dried at $55-60^{\circ} \mathrm{C}$ for a period of 24 hours. Shell thickness was obtained by using a Mitutoyo Digital micrometer 0-25 mm with a precision of 0.001 mm. For the analysis of specific gravity, the methodology described by Hamilton (1982) was followed.

Statistical analysis was carried out using SAS (2011) and treatments were compared to the control treatment by Dunnett's test at $5 \%$ probability. The requirement of methionine plus cystine was estimated by regression analysis.

\section{Results and Discussion}

Egg production, weight, mass and feed conversion per egg mass and dozen were significantly different $(\mathrm{P}<0.05)$, when submitted to the Dunnet test (Table 2). Feed intake showed no differences between treatments $(\mathrm{P}>0.05)$.

Table 2 - Feed intake (FI, g/bird/day), egg production (EP, \%), egg weight (EW, g), egg mass (EM, g), feed conversion per egg mass (FCM, g/g) and feed conversion per dozen eggs (FCD, kg/dz) of light laying hens, aged 34 to 50 weeks.

\begin{tabular}{ccccccccc}
\hline Treatment & & MET:LYS & FI & EP $^{3}$ & EW & EM $^{4}$ & FCM $^{5}$ & FCD $^{6}$ \\
\hline NRC (1994) & 80 & 64 & 103.35 & 91.43 & 64.15 & 58.46 & 1.78 & 1.37 \\
\hline & 90 & 73 & 104.14 & $88.13 ¥$ & $61.82 ¥$ & $54.48 ¥$ & $1.92 ¥$ & $1.42 ¥$ \\
Rostagno et al. (2011) & 100 & 81 & 104.23 & $89.07 ¥$ & $62.36 ¥$ & $55.56 ¥$ & $1.88 ¥$ & $1.41 ¥$ \\
& 110 & 90 & 102.65 & $88.69 ¥$ & $62.33 ¥$ & $55.28 ¥$ & $1.85 ¥$ & 1.39 \\
& 120 & 98 & 102.52 & $87.40 ¥$ & $62.29 ¥$ & $54.43 ¥$ & $1.89 ¥$ & $1.41 ¥$ \\
\hline Regression & & & $\mathrm{ns}$ & $\mathrm{Q} *$ & $\mathrm{~ns}$ & $\mathrm{Q}^{*}$ & $\mathrm{Q}^{*}$ & $\mathrm{Q}^{* *}$ \\
\hline C.V. (\%) & & & 2,00 & 4,07 & 3,56 & 5,55 & 5,79 & 4,36 \\
\hline REQ & & & 0,691 & & 0,689 & 0,737 & 0,73 \\
\hline
\end{tabular}

${ }^{1}$ Methionine plus cystine:lysine ratio (\%);C.V.(\%): Coefficient of variation; ¥: different means by Dunnett test at 5\% probability; Q*: quadratic effect at $5 \%$ probability; $\mathrm{Q}^{* *}$ : quadratic effect at $1 \%$ probability.; ns: non significant. ${ }^{2}$ Requirement of methionine plus cysteine (\%) according to derivation of polynomial equation. ${ }^{3} \hat{Y}=-0.0057 x 2+1.1779 x+28.512, R^{2}=0.99 ;{ }^{4} \hat{Y}=0.000064 x^{2}-0.013957 x+2.156000, R^{2}=0.93 ;{ }^{5} \hat{Y}=-0.0029 x^{2}+0.6001 x+24.464, R^{2}=0.86 ;$ ${ }^{6} \hat{\mathrm{Y}}=0.0000643 \mathrm{x}^{2}-0.0141571 \mathrm{x}+2.6520000, \mathrm{R}^{2}=0.65$. Source: Authors.

The birds fed the control diet (NRC, 1994) showed higher production, weight and egg mass, and lower feed conversion per egg mass when compared with animals fed increasing levels of methionine plus cystine based on the Brazilian Tables recommendations (Rostagno et al., 2011). 
The levels of arginine, isoleucine and lysine in the diet established by the NRC (1994) are above the values suggested by Rostagno et al. (2011) and it is possible that the diets that have been formulated based on the nutritional Met + Cis requirements of Brazilian tables did not meet the requirements of these other amino acids, resulting in lower performance when compared with animals fed diets based on total amino acid.

The current strains of commercial layers have better ability to use dietary nutrients and convert them into egg weight and mass. In order to support the high production rates, the nutritional requirements increase substantially. It is thus possible that birds fed diets formulated based on the nutritional requirements of the NRC (1994) showed better utilization of nutrients and this was expressed as best production, egg weight, egg mass and feed conversion per egg mass and dozen.

Albeit the higher levels of essential amino acids in diets (NRC, 1994), particularly arginine, lysine and isoleucine, performance was not impaired as a result of possible excess of nitrogen in diet. According Koelkebeck et al. (1991), highproduction laying hens showed some tolerance to excess amino acids present in corn-soybean meal diets.

Nevertheless, diets based on digestible amino acids contribute to a greater accuracy in the supply of amino acids, since the ability of the bird to use the amino acids from food increases and it is possible to overcome any differences in digestibility of ingredients (Rombola et al., 2008).

The lower yield of birds fed diets formulated as recommended by Rostagno et al. (2011) can be explained by the possible deficiency of essential amino acids in the diet, such as lysine, arginine and isoleucine. According to Jordão Filho et al. (2006), the essential amino acids are required to fulfill three basic requirements of laying hens: maintenance, formation of body tissue and protein deposition in the egg. Besides, errors in the concentration of essential dietary amino acids can compromise the productive performance, especially methionine, which deficiency may reduce production and egg weight. According to Figueiredo Jr et al. (2020), the proper methionine nutritional level boost productive performance rates, tissue formation, and the functioning of physiological systems.

The different bases for diet formulation (total amino acids vs digestible amino acids) and the methionine plus cystine levels (Rostagno et al., 2011) were not able to significantly affect the feed intake of animals. The lack of significant difference ( $P$ > 0.05) in feed intake in this study corroborates the results found in other studies that evaluated the levels of methionine plus cystine for laying hens (Sá et al., 2007; Cupertino et al., 2009; Varela, 2009; Polese et al., 2012).

However, the behavior of feed intake is quite controversial, since studies that evaluated increasing levels of sulfur amino acids in the diets of laying hens have already reported either a decrease (Jordão Filho et al., 2006) or an increase in feed intake (Harms et al., 1998; Barbosa et al., 2009; Brumano et al., 2010). Feed intake can be affected by many factors such as ambient temperature, relative humidity, dietary levels of nutrients, stress, among others, which may explain the wide variation of responses of animals related to food consumption.

The levels of sulfur amino acids had no significant effect on the quality of the eggs in the present study $(\mathrm{P}>0.05)$, neither by the Dunnet test, nor by linear or quadratic regression analysis (Table 3). 
Table 3 - Yolk percentage (YP, \%), albumen percentage (AP, \%), shell percentage (SP, \%), shell thickness (ST, mm), specific gravity (SG, g/ml) of light laying hens, aged 34 to 50 weeks.

\begin{tabular}{cccccccc}
\hline Treatment & & MET:LYS & YP & AP & SP & ST & SG \\
\hline NRC (1994) & & 84 & 26.06 & 59.22 & 9.79 & 511.69 & 1.085 \\
\hline & 80 & 65 & 26.36 & 60.63 & 10.06 & 515.03 & 1.086 \\
& 90 & 73 & 27.05 & 59.17 & 10.05 & 520.42 & 1.086 \\
Rostagno et al. (2011) & 100 & 81 & 26.23 & 59.97 & 9.93 & 520.36 & 1.086 \\
& 110 & 90 & 26.54 & 60.19 & 10.00 & 516.06 & 1.086 \\
& 120 & 98 & 27.08 & 59.09 & 10.24 & 515.34 & 1.086 \\
\hline Regression & & & $\mathrm{ns}$ & $\mathrm{ns}$ & $\mathrm{ns}$ & $\mathrm{ns}$ & $\mathrm{ns}$ \\
\hline C.V. (\%) & & & 1.60 & 1.07 & 1.50 & 5.02 & 0.21 \\
\hline
\end{tabular}

${ }^{1}$ Methionine plus cystine:lysine ratio (\%);C.V.(\%): Coefficient of variation; ns: non significant. Source: Authors.

These data corroborate previous studies in which methionine plus cystine have also not affected egg quality (Jordão Filho et al., 2006; Sá et al., 2007; Varela, 2009; Polese et al., 2012). It is possible that the dietary levels of this study were not sufficient to cause significant changes in the quality of internal and external components of eggs.

On the other hand, Mendonca Jr and Lima (1999), Barbosa et al. (2009) and Brumano et al. (2010) found a significant influence of sulfur amino acids levels on egg quality of laying hens. Although they are not present in significant amounts in the internal components of egg chicken (Pires et al., 2006), the sulfur amino acids are directly involved in the organic protein synthesis and can influence the egg quality of laying hens.

Based on data from the regression analysis, there was a quadratic effect on egg production $(\hat{\mathrm{Y}}=-0.0057 \mathrm{x} 2+1.1779 \mathrm{x}+$ $\left.28.512, \mathrm{R}^{2}=0.99 ; P<0.01\right)$, feed conversion per dozen eggs $\left(\hat{\mathrm{Y}}=0.0000643 \mathrm{x}^{2}-0.0141571 \mathrm{x}+2.6520000, \mathrm{R}^{2}=0.65 ; P<0.01\right)$, egg mass $\left(\hat{\mathrm{Y}}=0.000064 \mathrm{x}^{2}-0.013957 \mathrm{x}+2.156000, \mathrm{R}^{2}=0.93 ; P<0.05\right)$ and feed conversion per egg mass $\left(\hat{\mathrm{Y}}=-0.0029 \mathrm{x}^{2}+\right.$ $\left.0.6001 \mathrm{x}+24.464, \mathrm{R}^{2}=0.86 ; P<0.05\right)$.

From the derived equations, the level of methionine plus cystine estimated for egg production, egg mass, egg mass conversion and conversion per dozen eggs is $103,25 \%(0,691 \%$ methionine plus cystine), $102,91 \%(0,689 \%$ methionine plus cystine), $110,03 \%$ (0,737\% methionine plus cystine) and 109,03\% (0,730\% methionine plus cystine), respectively.

The estimated methionine plus cystine requirement for the variables related to feed conversion are greater to the variables of production and egg mass. Similarly, Schutte et al. (1994) reported that the methionine plus cystine level required to optimize feed conversion of birds is higher than that for maximizing the production of eggs.

Based on the results of animal performance obtained in this study and the biological responses of animals, and considering the levels of sulfur amino acids that have been evaluated, the level of methionine plus cystine corresponding to feed conversion per dozen eggs is recommended for feeding the animals, in other words, $0.730 \%$ of methionine plus cystine for light laying hens from 34 to 50 weeks old.

The estimated values for sulfur amino acids in this study are greater than the recommended level in the Dekalb White manual, which recommends $0.660 \%$ methionine plus cystine during the laying phase. Similarly, the estimated level of sulfur amino acids in this study are higher than those of the similar research in recent years.

In that sense, a significant increase in the nutritional requirements for sulfur amino acids for laying hens in production has been observed in recent studies. This fact is mainly attributed to genetic improvement, which made the birds more efficient and with improved performance, and the tables of nutritional requirements for laying hens in production must be always reviewed and updated. Corroborating this fact, Sá et al. (2007) reported that the differences in the values of the requirement for methionine 
plus cystine in layers become evident, especially with changes in genetics, nutrition and management that birds are subject, beyond the effects of age, type of diet and environmental conditions.

Togashi et al. (2002) determined the level of $0.565 \%$ methionine plus cystine for laying hens fed on diets containing stance dry yeast (Saccharomyces cerevisiae). Sá et al. (2007) and Cupertino et al. (2009) estimated the sulfur amino acid requirements for light laying hens in production and recommended the level of 0.693 and $0.655 \%$ methionine plus cystine, respectively.

More recently, Brumano et al. (2010) evaluated the methionine plus cystine levels for laying hens during 42-58 weeks old and estimated the level of sulfur amino acids to the stage at $0.775 \%$, close to the value estimated in this study $(0.730 \%)$.

According to Waldroup and Hellwig (1995), the requirements of sulfur amino acids for laying hens have a peak for egg production in the period comprising between $51^{\mathrm{a}}$ and $58^{\mathrm{a}}$ weeks old, probably by increasing the size of the eggs. In the present study, the evaluation period of the experimental diets was close to the phase of peak demand for methionine for laying, and thus may explain the estimated level in this study was significantly higher than the recommended values in the main tables of nutrient requirements.

The birds fed the lowest levels of sulfur amino acids ( 80 and 90\%), as well as the animals that received treatment with $120 \%$ methionine plus cystine, had lower production, weight and egg mass, and impaired feed conversion. Thus, it can be inferred that the amino acid imbalance, caused either by deficiency or excess of sulfur amino acids in the diet, results in losses in the production of egg chicken. Similarly, Jordão Filho et al. (2006) reported a reduction in egg weight of laying hens in extreme levels of methionine plus cystine, which were explained by the authors as the effect of the deficiency and excess dietary sulfur amino acid on this variable.

According to D'Mello (2003), methionine have a key role in metabolism as a donor of methyl groups active. Furthermore, it has an important role as precursor of homocysteine and cysteine, which are essential for the body in the synthesis of various enzymes involved in protein metabolism. Jordão Filho et al. (2006) reported increased fat deposition in the liver when dietary levels of amino acids were not optimal, especially methionine and lysine.

The amino acid imbalance caused by methionine deficiency causes negative effects on feed intake, growth rate and productivity of broiler chickens and laying hens (Pars; Summers, 1991; Narváez-Solarte,1996).

Among the essential amino acids, sulfur amino acids are amongst the most toxic to non-ruminants, mainly because it contains sulfur in its composition. Thus, the excess of methionine plus cystine in the diet with $120 \%$ of the nutritional requirements for this amino acid possibly caused toxicity to animals, mainly by reducing the production and feed efficiency in the period. In this sense, the photomicrographs of the liver of birds (Figure 1) show that birds fed the control diet (NRC, 1994) and diet with $120 \%$ of methionine plus cystine presented hepatic parenchymal disorganization, due to a greater accumulation of cytoplasmic vacuoles in liver cells. 
Figure 1 - Photomicrography of liver of light laying hens with 50 weeks old supplemented with methionine plus cystine levels. A) Image representing the control treatment (NRC, 1994); B) Image representing the treatments with 80 and $90 \%$ of digestible methionine plus cystine (Rostagno et al., 2011); C) Image representing the treatments with 100 and $110 \%$ of digestible methionine plus cysteine (Rostagno et al., 2011); D) Image representing the treatment with 120\% of digestible methionine plus cystine (Rostagno et al., 2011). Periodic acid Schiff coloring. Bars: $400 \mu \mathrm{m}$.

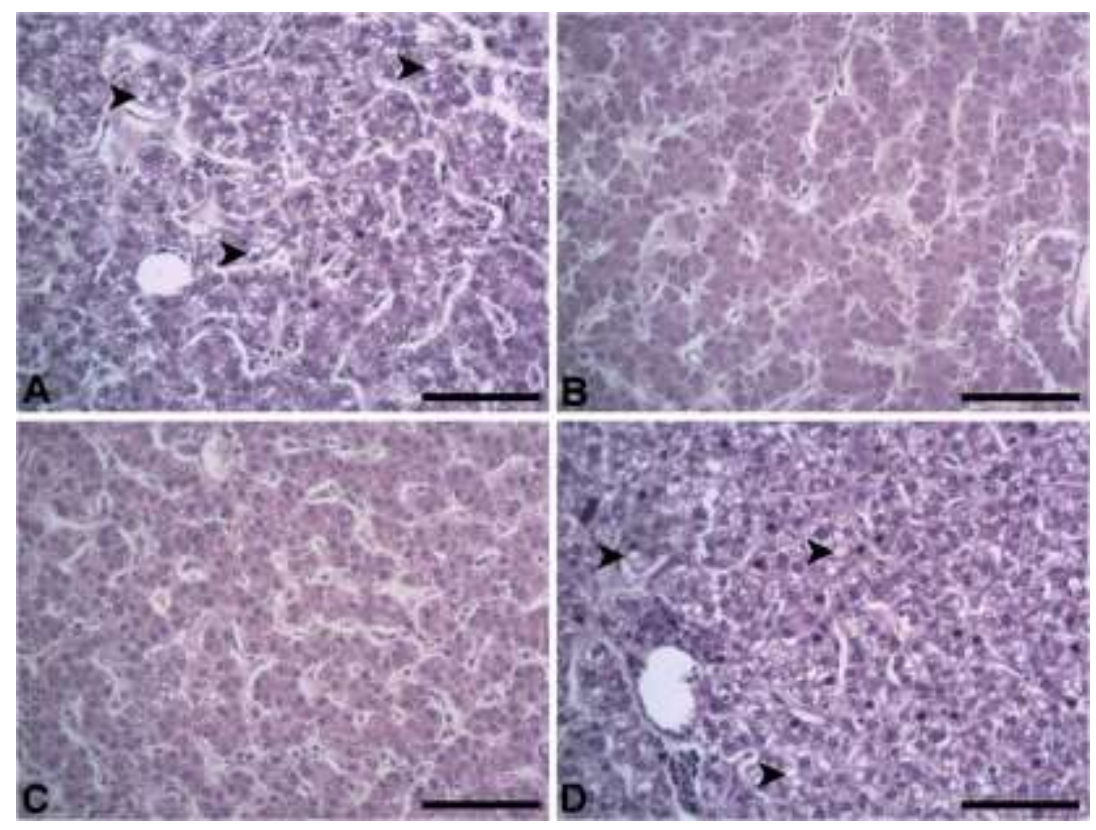

Source: Authors.

Furthermore, the birds of these treatments also presented greater accumulation of liver glycogen, represented by the largest positive staining for periodic acid Schiff. In contrast, the liver of birds of treatments with $80,90,100$ and $110 \%$ of methionine plus cystine showed no evidence of steatosis or hepatic parenchymal disorganization, and less accumulation of liver glycogen to be observed, with lower positive staining periodic acid Schiff, when compared with the other treatments.

These results are consistent with the findings in the study conducted by Bunchasak and Silapasorn (2005), who reported an increase in liver fat of laying hens that received high levels of methionine in the diet. These authors also stated that the increase in liver fat of the birds may have been caused by increased estrogen synthesis in the ovary, in detriment of the high rates of egg production, corroborating the data of this study, where higher rates of egg production were observed in the control treatment (NRC, 1994).

Liver cells are involved in processes of protein synthesis, bile secretion, glycogen storage, biotransformation and detoxification and metabolism of amino acids, lipids and glucose, among other functions (Takashima; Hibiya, 1995). Probably the levels of methionine plus cystine changed hepatic metabolism, evidenced by greater accumulation of liver glycogen of animals of control treatment (NRC, 1994) and birds fed the $120 \%$ level of methionine plus cystine.

Although a moderate hepatic steatosis is seen in these treatments, probably the effects of this metabolic disorder did not interfere directly on the results of animal performance, since the improved production rates were found in animals receiving the control diet (NRC, 1994). Allied to this, at this age the animals already have all the organs and systems developed and the excess of energy may have been stored in the liver and used for other functions such as egg production (Bunchasak; Silapasorn, 2005).

Regarding images of photomicrographs of the small intestine of birds (Figure 2) fed levels of sulfur amino acids, it is observed that the animals that received the lowest levels of methionine plus cystine (Figure 2A) showed smaller width of 
intestinal villi. The animals that received the control treatment (NRC, 1994) and levels 100, 110 and 120\% of methionine plus cystine of Brazilian tables, showed greater width of intestinal villi.

Figure 2 - Photomicrography of small intestine of light laying hens with 50 weeks old supplemented with methionine plus cystine levels. A) Image representing the treatments with 80 and $90 \%$ of digestible methionine plus cystine (Rostagno et al., 2011); B) Image representing the treatments with 100, 110 and 120\% of digestible methionine plus cystine (Rostagno et al., 2011) and the control treatment (NRC, 1994), which showed villi with greater width (vertical bar) and more branches (arrowheads). Hematoxylin-eosin coloring. Bars: $400 \mu \mathrm{m}$.

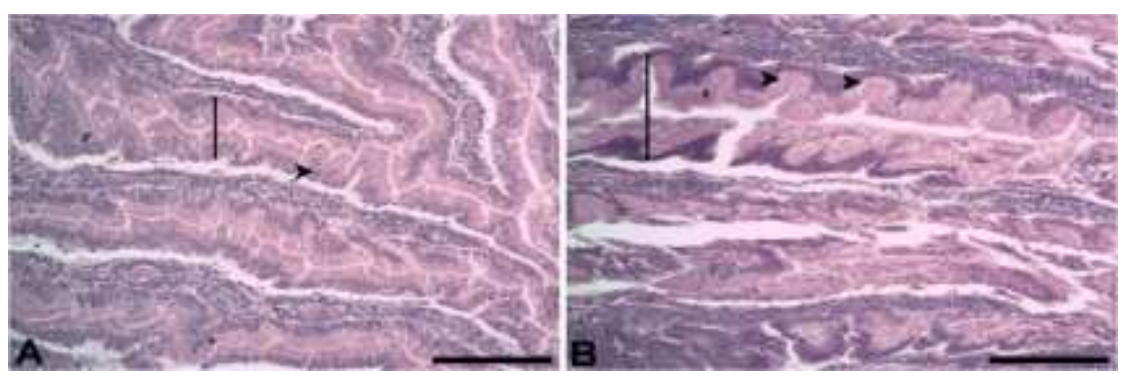

Source: Authors.

The increased villus width and height are directly connected to a larger area of nutrient absorption in the small intestine, since this organ is the main site of digestion and uptake of nutrients in the body. Several ingredients have been used in nutrition with trophic function of the intestinal mucosa, especially the synthetic amino acids (Soares et al., 2008; Lima et al., 2012). In this sense, methionine, the first limiting amino acid for poultry production in diets based on corn and soybean meal and a key element in the process of protein synthesis in the body, have direct participation in intestinal development.

Soares et al. (2008) observed better development of the structures of the small intestine of broiler chicks with seven days old and supplemented with methionine in the diet. In contrast, Zavarize et al. (2011) did not observe representative morphological changes in the intestinal mucosa of laying hens subjected to heat stress and thermoneutral and supplemented with glutamine in the diet.

However, according to Rezende and Beletti (2008), regardless of the intestinal segment considered, villus height and width intensely increased until the birds were nine weeks-old, and afterwards there was a tendency to stabilize. Thus, it is possible that the sulfur amino acid deficiency caused a reduction in the ability of the process of renewal of the epithelial cells of the small intestine, with a reduction of the width of the villus in birds fed the lower levels of methionine plus cystine compared with the other treatments.

Active albumen glands are seen in the magnum of birds of all treatments (Figure 3). However, animals fed diets with 80 and $90 \%$ of methionine plus cystine (Figure 3B) showed a reduced amount of albumen secretory cells in the magnum compared to the birds fed the control treatment (Figure 3A) and the animals of 100, 110 and 120\% of methionine plus cystine, which showed a higher amount of active glands compared to the other treatments. 
Figure 3 - Photomicrography of magnum of light laying hens with 50 weeks old supplemented with methionine plus cystine levels. A) Image representing the control treatment (NRC, 1994); B) Image representing the treatments with 80 and $90 \%$ of digestible methionine plus cystine (Rostagno et al., 2011); C) Image representing the treatments with 100,110 and $120 \%$ of digestible methionine plus cystine (Rostagno et al., 2011). Asterisk representing active glands of the magnum. Hematoxylineosin coloring. Bars: $200 \mu \mathrm{m}$.
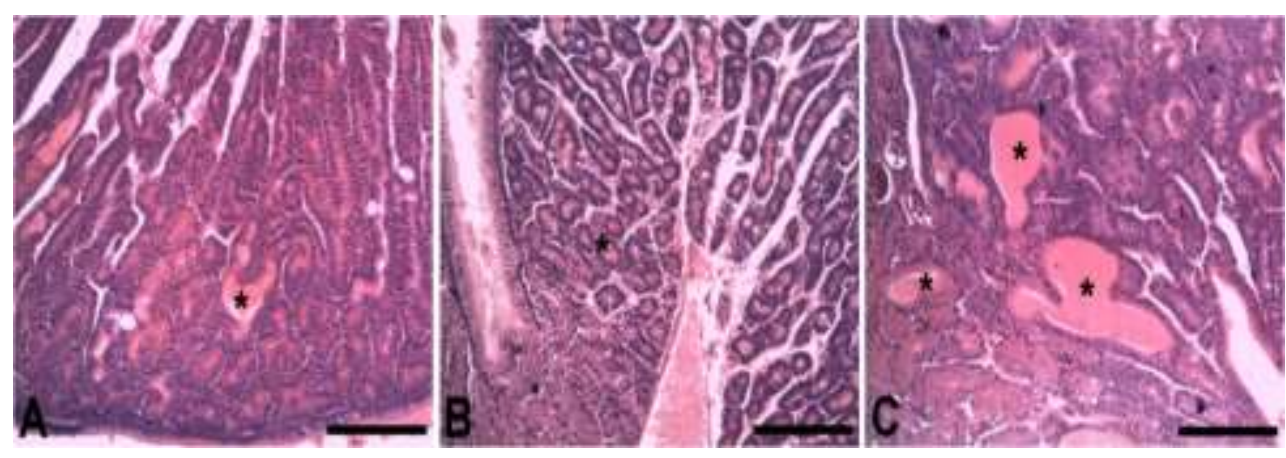

Source: Authors.

A similar effect was reported by Lima et al. (2012), who observed increased of activity of albumen glands in the magnum and consequent increased production of albumen in light laying hens supplemented with dietary digestible tryptophan.

The increase of the folds of the magnum, together with greater activity of this organ and largest stock of albumen, allows egg production in a shorter period, increasing productivity and weight and egg mass (King; Mclelland, 1979). Thus, the better development of the organ and the largest stock of albumen, mainly in animals fed the control diet and the highest levels of methionine plus cystine of Brazilian tables, allowed greater production, weight and egg mass, and a better feed conversion, as demonstrated in animal performance data.

The photomicrographs of the uterus of the bird showed no significant histological changes between treatments, however, it can be seen that the birds of treatments with the 110 and $120 \%$ methionine plus cystine had a greater width of uterus folds (Figure 4).

Figure 4 - Photomicrography of uterus of light laying hens with 50 weeks old supplemented with methionine plus cystine levels. A) Image representing the treatments with 80 and $90 \%$ of digestible methionine plus cystine (Rostagno et al., 2011); C) Image representing the treatments with 100, 110 and $120 \%$ of digestible methionine plus cystine (ROSTAGNO et al., 2011) and the

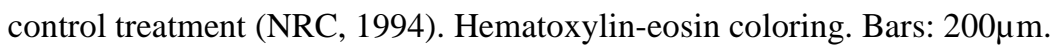

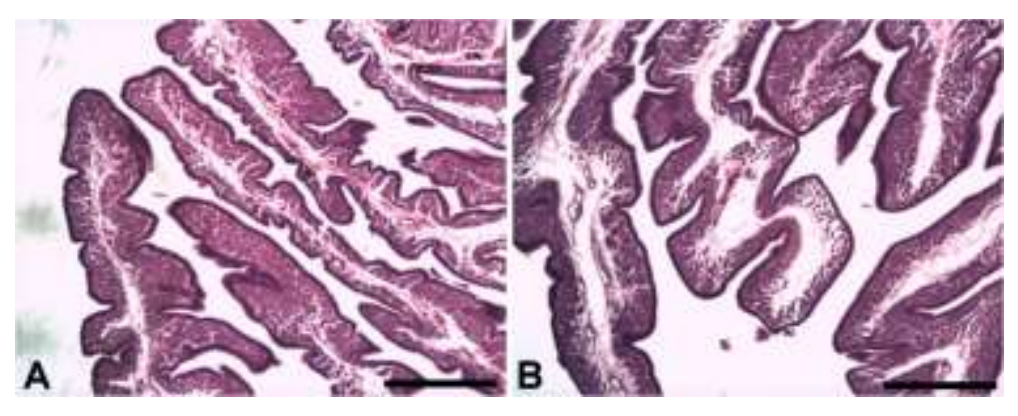

Source: Authors.

Corroborating these data, Lima et al. (2012) observed that supplementation of tryptophan in the diet of laying hens in production phase provides further development and high amount of secondary folds in the uterus of birds, and hyperplasia of the organ. 
According to King and McLelland (1979), further development of the uterus folds also corroborates for the egg production since the process of formation and deposition of calcium carbonate crystals in the eggshell occurs more efficiently. However, these changes in the development of the uterus of the birds were not sufficient to alter the quality of the egg shell, because no significant differences for percentage and shell thickness were found, and specific gravity.

Organ weight at 50 weeks of age was similar $(\mathrm{P}>0.05)$ between treatments with different formulations (total vs digestible amino acids), by Dunnet's test, as well as between levels of methionine plus cystine, by regression analysis (Table 4).

Table 4 - Relative weight (\%) of spleen (SPL), liver (LIV) and celomatic fat (CF) of light laying hens with 50 weeks old.

\begin{tabular}{cccccc}
\hline Treatment & & MET:LYS $^{1}$ & SPL & LIV & CF \\
\hline NRC (1994) & & 93 & 0.100 & 2.58 & 3.03 \\
\hline & $80 \%$ & 66 & 0.119 & 2.66 & 2.22 \\
Rostagno et al. (2011) & $90 \%$ & 74 & 0.105 & 2.79 & 2.23 \\
& $100 \%$ & 82 & 0.094 & 2.73 & 1.98 \\
& $110 \%$ & 90 & 0.098 & 2.65 & 2.41 \\
& $120 \%$ & 98 & 0.091 & 2.73 & 2.16 \\
\hline Regression & & & $\mathrm{ns}$ & $\mathrm{ns}$ & $\mathrm{ns}$ \\
\hline C.V. (\%) & & & 9.87 & 2.77 & 15.64
\end{tabular}

${ }^{1}$ Methionine plus cystine:lysine ratio (\%); C.V.(\%): coefficient of variation; ns: non significant. Source: Authors.

The lack of significant differences for these variables, especially the liver and spleen, can be explained by the growth and development of these organs occur mainly in the first weeks of life, where it is possible to observe differences in organ weights from the manipulation levels of dietary nutrients.

According to Bertechini (2012), the growth of replacement pullets follows the multiphase physiological model. In this model, there is physiological priority of visceral growth (vital organs) from 1 to 5 weeks, followed by bone growth between 6 and 12 weeks and reproductive organs from 12 to 16 weeks old, increasing bone density and accumulation of body reserves for early production. Thus, the increase in weight of visceral organs in laying hens is most evident during the growth phase and in the weeks before laying. High levels of methionine have been reported to increase the metabolic activity of the liver in layers during the growth phase, evidencing that this amino acid affects both the carcass characteristics and visceral organs (SAKI et al., 2011). Similarly, Hazelwood et al. (1986) reported that the liver of laying hens increases weight in periods prior to the laying phase.

Similarly, the levels of dietary amino acids may also influence the metabolic activity and consequently the weight of the spleen, which is an organ directly connected to the immunological activity of birds. According to Carvalho (2012), the activity of immune system in birds can be improved by sulfur amino acids. However, the nutritional requirements for immune responses in animals differ from those for growth and tissue deposition (KIDD, 2004), and this fact may explain the lack of significant difference between treatments for spleen weight of the birds.

The different forms of feed formulation (total amino acids vs digestible amino acids), and the methionine plus cystine levels of Brazilian tables were not able to change the fat accumulation of body of birds during the trial period. On the contrary, excess of sulfur amino acids have been reported to increase fat accumulation in the abdominal cavity and limit the accumulation of lean tissue at 42-day-old broilers (SILVA Jr et al., 2005), probably due to the amino acid imbalance of diets. In the present study, although no significant differences were seen in fat weight percentage of abdominal fat of birds, control animals showed greater accumulation of liver glycogen (Figure 1), probably due to the excess amino acids in the diet. 


\section{Final Considerations}

- It is recommend the level of $0.730 \%$ methionine plus cystine, with methionine plus cystine: lysine ratio of $99 \%$ and corresponding to the approximate consumption of methionine plus cystine $751.24 \mathrm{mg} / \mathrm{bird} / \mathrm{day}$ for laying hens from 34 to 50 weeks old;

- Supplementation with methionine plus cystine in the diet of laying hens improves the development and activity of the magnum and uterus, as well as increasing the width of intestinal villi;

- Birds fed diet based on total amino acids, as well as the animals that received the highest level of methionine plus cystine present greater accumulation of glycogen and hepatic parenchymal disorganization;

- The levels of methionine plus cystine did not alter the weight of the spleen, liver and abdominal fat;

- With the advancement of genetic improvement, more research must be carried out to determine the nutritional requirements of methionine + cystine, as well as its bioavailability.

\section{Acknowledgments}

Special thanks to Coordenação de Aperfeiçoamento de Pessoal de Nível Superior, Granja Planalto (Uberlândia, Minas Gerais, Brazil), and Adisseo Animal Nutrition (São Paulo, Brazil).

\section{References}

ABPA. 2020. Relatório Anual 2020. Associação Brasileira de Proteína Animal (ABPA).

Barbosa, M. J. B., R. M. Cardozo, V. L. F. Souza, et al. (2009). Níveis de metionina + cistina no desempenho de poedeiras comerciais leves com 45 semanas de idade. Rev. Bras. de Saúde e Prod. Animal. 10:1032-1039.

Bertechini, A. G. (2012). Nutrição de Monogástricos. (2nd ed.) UFLA. Brazil.

Brumano, G., P. C., \& Gomes, J. L. Donzele. (2010). Níveis de metionina + cistina digestível para poedeiras leves no período de 24 a 40 semanas de idade. Rev. Bras. de Zootec. 39, 1228-1236.

Bunchasak, C., \& T. Silapasorn. (2005). Effects of adding methionine in low-protein diet on production performance, reproductive organs and chemical liver composition of laying hens under tropical conditions. Int. J. Poult. Sci. 4:301-308.

Carvalho, C. B. (2012). Níveis de metionina+cistina e suas relações com a lisina em rações para poedeiras leves no período de 79 a 95 semanas de idade. $P h D$ Thesis. Universidade Federal de Viçosa, Viçosa, Minas Gerais, Brazil.

Cupertino, E. S., P. C., Gomes, H. S., Rostagno, et al. (2009). Exigência nutricional de metionina + cistina digestíveis para galinhas poedeiras de 54 a 70 semanas de idade. Rev. Bras. de Zootec. 38:1238-1246.

D’Mello, J. P. F. (2003). Amino Acids in Animal Nutrition. Wallingford: CABI International.

Hamilton, R. M. G. (1982). Methods and factors that affect the measurement of eggshell quality. Poultry Science, 61, $2002-2039$.

Harms, R. H., G. B., Russel, H., Herlow, et al. (1998). The influence of methionine on commercial laying hens. J. Appl. Poultry Res. 7:45-52.

Hazelwood, R. L. (1986). Carbohydrate metabolism. Pages 303-325 in Avian Physiology. P. D. Sturkie, ed. Spring-Verlag.

Jordão Filho, J., J. H. V. Silva, E. S. Silva, et al. (2006). Exigências nutricionais de metionina + cistina para poedeiras semipesadas do início de produção até o pico de postura. Rev. Bras. de Zootec. 35:1063-1069.

Kidd, M. T. (2004). Nutritional modulation of immune function in broilers. Poult. Sci. 83:650-657.

King, A. S., \& J. McLelland. (1979). Form and function in birds. Academic Press.

Koelkebeck, K. W., Baker, D. H. Y., Han, et al. (1991). Research note: effect of excess lysine, methionine, threonine, or tryptophan on production performance of laying hens. Poult. Sci. 70:1651-1653.

Leeson, S., J. D. Summers, \& L. J. Caston. (2001). Response of layers to low nutrient density diets. J. Appl. Poultry Res. 10:46-52.

Lima, M. R., F. G. P. Costa, R. R. Guerra, et al. (2012). Digestible tryptophan:lysine ratios for laying hens. Rev. Bras. de Zootec. 41:2203-2210.

Mendonca JR., C. X., \& F. R. Lima. (1999). Efeito dos níveis de proteína e de metionina da dieta sobre o desempenho de galinhas poedeiras após a muda forçada. J. Vet. Res. and Animal Sci. 36:332-338. 
Narváez-Solarte, W. V. (1996). Exigências em metionina+cistina para poedeiras leves e semipesadas. PhD Diss. Universidade Federal de Viçosa, Viçosa, Minas Gerais, Brazil.

NRC. (1994). Nutrient Requirements of Poultry. (9th ed.), Natl. Acad. Press.

Pars, J. F., \& Summers, J. D. (1991). The effects of minimizing amino acid excess in broiler diets. Poult. Sci. 70:1540-549.

Pires, C. V., M. G. A. Oliveira, J. C. Rosa, et al. (2006). Qualidade nutricional e escore químico de aminoácidos de diferentes fontes proteicas. Ci. Tecnol. Aliment. 26:179-187.

Polese, C., R. V. Nunes, C. G. Vilela, et al. (2012). Quantidade de metionina + cistina para poedeiras semipesadas de 75 a 91 semanas de idade. Arq. Bras. de Med. Vet. e Zootec. 64:1682-1690.

Rezende, B. J., \& Beletti, M. E. (2008). Análise histomorfométrica do desenvolvimento do intestino delgado de galinhas poedeiras. CD-ROM in XII Seminário de Iniciação Científica, Uberlândia, Minas Gerais, Brazil.

Rombola, L. G., D. E. Faria, B. J. \& Deponti, et al. (2008). Fontes de metionina em rações formuladas com base em aminoácidos totais ou digestíveis para frangas de reposição leves e semipesadas. Rev. Bras. de Zootec. 37:1990-1995.

Rostagno, H. S., L. F. T. Albino, J. L. Donzele, et al. (2011). Tabelas brasileiras para aves e suínos: composição de alimentos e exigências nutricionais. 3rd ed. Universidade Federal de Viçosa, Viçosa, Minas Gerais, Brazil.

Sá, L. M., P. C. Gomes, L. F. T. Albino, et al. (2007). Exigência nutricional de metionina + cistina digestível para galinhas poedeiras no período de 34 a 50 semanas de idade. Rev. Bras. de Zootec. 36:1837-1845.

Saki, A. A., F. Mirzaaghatabar, P. Zamani, et al. (2011). Energy utilization by chickens fed various levels of balanced methionine. Glob. Vet. 7:276-282.

SAS Institute Inc. (2011). SAS User's guide: Statistics. SAS Inst. Inc., Cary, NC.

Schutte, J. B., J. \& De Jong, H. L. (1994). Bertram. Requirement of the laying hen for sulfur amino acids. Poult. Sci. 73:274-280.

Silva Junior, R. G. C., G. R. Q. Lana, C. B. V. Rabello, et al. (2005). Exigências de metionina + cistina para frangos de corte machos de 1 a 21 e de 22 a 42 dias de idade, em clima tropical. Rev. Bras. de Zootec. 34:2399-2407.

Soares, A. D. M., P. E. N. Givisiez, E. G. Santos, et al. (2008). Efeito dos níveis de metionina + cistina digestíveis da dieta pré-inicial sobre a morfometria intestinal de frangos de corte. CD-ROM in Proc. Congresso Brasileiro de Zootecnia, João Pessoa, Paraíba, Brazil.

Togashi, C. K., J. B. Fonseca, \& R. T. B. N. Soares. (2002). Determinação de níveis de metionina + cistina para poedeiras semipesadas alimentadas com rações contendo Levedura Seca (Saccharomyces cerevisae). Rev. Bras. de Zootec. 31:1426-1433.

Takashima, F., and T. Hibiya. (1995). An atlas of fish histology. Normal and Pathological features. (2nd ed.), Fisher.

Varela, E. V. (2009). Níveis nutricionais de metionina + cistina digestíveis em poedeiras Hy Lyne W36 com base no conceito de proteína ideal. PhD Diss. Univ. Estadual de Maringá, Maringá, Paraná, Brazil.

Waldroup, P. W., \& Hellwig, H. M. (1995). Methionine and total sulfur amino acid requirements influenced by stage of production. J. Appl. Poultry Res. 4:283292.

Zavarize, K. C., J. R. Sartori, A. C. Pezzato, et al. (2011). Glutamina na dieta de poedeiras leves submetidas ao estresse por calor e à termoneutralidade. Cienc. Anim. Bras. 12: 400-406. 